\title{
ESTABLISHMENT OF THE EFFICIENCY OF ANIMAL BREEDING PREMISES DISINFECTION BY MODERN DISINFECTANTS
}

\author{
Andriy Paliy \\ Department of Technical Systems and Animal Husbandry Technologies \\ Kharkiv Petro Vasylenko National Technical University of Agriculture \\ 45 Moskovsky ave., Kharkiv, Ukraine, 61050 \\ paliy.andriy@ukr.net \\ Anatoliy Paliy \\ Laboratory of Veterinary Sanitation and Parasitology \\ National Scientific Center "Institute of Experimental and Clinical Veterinary Medicine» \\ 83 Pushkinska str., Kharkiv, Ukraine, 61023 \\ paliy.dok@gmail.com \\ Alexander Nanka \\ Kharkiv Petro Vasylenko National Technical University of Agriculture \\ 45 Moskovsky ave., Kharkiv, Ukraine, 61050 \\ nanka-1@i.ua \\ Olga Chalaya \\ Department of Agrotechnology and Ecology \\ Kharkiv Petro Vasylenko National Technical University of Agriculture \\ 45 Moskovsky ave., Kharkiv, Ukraine, 61050 \\ chaliolisobol@gmail.com \\ Oleksandr Chalyi \\ Department of Livestock and Poultry Technologies \\ Kharkiv State Zooveterinary Academy \\ 1 Academichna str., Mala Danylivka, Dergachi district, Kharkiv region, Ukraine, 62341 \\ chalyialex64@gmail.com
}

\begin{abstract}
The technological complex of veterinary-sanitary and organization-economic arrangements, conducted for prophylaxis and fight against infectious diseases inevitably includes disinfection, directed on inactivation of pathogenic agents in the environment. At applying new disinfectants in practice in the whole structure of the technological process of animal husbandry products, it is necessary to determine their sensitivity to the circulating microflora. The aim of the study was to establish the effectiveness of using new disinfecting preparations of different chemical groups and to determine regimes of their application in the whole complex of anti-epizootic prophylactic arrangements. Disinfecting preparations "Hermicidan FF plus", "Peroxan forte", "Viro-xal" were used in experiments. The quality of the conducted disinfection was controlled by separation of sanitary-representative microorganisms - bacteria of the colon bacillus group. It has been established, that the disinfecting preparations "Hermicidan FF plus", "Peroxan forte", "Viro-xal" have bactericidal properties relative to the sanitary-representative microorganisms and can be used in the general complex of sanitary-hygienic arrangements. The disinfectant "Hermicidan FF plus" has bactericidal properties in concentration $0,5 \%$ at exposition 1 hour, preparation "Peroxan Forte" is effective at using in concentration 1,0 \% at exposition 1 hour, and the disinfecting means "Viro xal" acts bactericidially in concentration 1,0\% at exposition 3 hours. For today the question of search for new technological, high-effective disinfecting preparations that correspond to existent requirements of biological safety and protection remains urgent.
\end{abstract}

Keywords: disinfection, disinfectant, bactericidal properties, chemical groups, microorganisms. 


\section{Introduction}

Disinfection of animal premises is an important condition for keeping welfare of the livestock as to infectious diseases and further rise of its productivity, it is a component of the general technological process of animal breeding products making and is conducted by the plan, formed taking into account epizootic and sanitary conditions and also husbandry peculiarities.

The problem of high-quality animal breeding products raises a series of tasks for agriculture workers, among which an important place is occupied by the development of a reliable technological system for protecting animals and humans from zoo-anthroponotic diseases.

The technological complex of veterinary-sanitary and organization-economic arrangements, conducted for prophylaxis and fight against infectious diseases inevitably includes disinfection, directed on inactivation of pathogenic agents in the environment [1,2].

Unsystematic and scientifically unfounded use of disinfectants resulted in formation of the increased resistance of microorganisms to their bactericidal effect [3]. There has been established the fact of circulation of tuberculosis mycobacteria, resistant not only to anti-tuberculosis preparations, but to widely used disinfecting substances that can be a cause of forming and spreading epizootic strains in isolated nidi [4].

One of ways of preventing resistance in microorganisms to antimicrobial preparations is a systematic and reasonable widening of the assortment of disinfecting means. The new promising direction is to develop disinfectants of the new generation, based on water-thinned paints, used for processing internal surfaces of animal breeding, poultry keeping premises, objects of veterinary control and equipment, building, finishing materials for eliminating causative agents of bacterial and viral diseases of animals and birds [5]. The disinfecting preparation Anolit ANK with a bactericidal effect as to gram-positive and gram-negative microorganisms is effective [6]. Preparations with aldehyde as a working substance remain promising for today $[7,8]$.

At applying new disinfectants in disinfection practice, it is necessary to determine their sensitivity to the circulating microflora.

The aim of the experiments was to establish the effectiveness of using the modern disinfecting preparations ("Hermicidan FF plus", "Peroxan forte", "Viro-xal") and to determine technological modes of their application (concentration and exposition) in the total complex of anti-epizootic prophylactic arrangements that allow to inactivate causative agents of diseases in the environment for providing animal breeding products of the high quality.

\section{Materials and methods}

The experimental work was conducted at animal farms of the Kharkiv region of Ukraine:

- SE CE "Kutuzovka", NAAS of Ukraine in Kharkiv region at free keeping of high-productive cows of the Ukrainian black-pitted milk breed;

- CE "Gontarovka" ABI NAAS of Ukraine at keeping of high-productive cows of the Ukrainian black-pitted milk breed and sharole breed and also sheep of the fine-fleeced milk-wool bred precos;

- PARE "Zorya” of Krasnograd district, Kharkiv region at free-box keeping of high-productive cows of the Ukrainian black-pitted milk breed;

- OASC "Agrocomplex "Slobozhansky" of Chuguev district, Kharkiv region at free-box keeping of high-productive cows of the Ukrainian black-pitted milk breed.

The following disinfecting preparations were used in the experiments:

- "Hermicidan FF plus" - liquid disinfecting means, consisting of didecyl dimethyl ammonium chloride - $50 \mathrm{~g} / 1$, glutaraldehyde - $245 \mathrm{~g} / 1$, propane-2-ol - $150 \mathrm{~g} / 1$, fetalcogolpolyglycoletter $50 \mathrm{~g} / \mathrm{l}$, nitrilotrimetilenetris - $50 \mathrm{~g} / \mathrm{l}$.

- "Peroxan Forte"- liquid disinfecting means, consisting of peracetic acid - $150 \mathrm{~g} / 1$, acetic acid - $190 \mathrm{~g} / \mathrm{l}$, hydrogen peroxide - $210 \mathrm{~g} / \mathrm{l}$.

- "Viro xal" - disinfecting means, consisting of alkyl dimethyl benzyl ammonium chloride $170,6 \mathrm{~g} / 1$, didecyl dimethyl ammonium chloride - $78 \mathrm{~g} / 1$, glutaraldehyde - 107,25 g/l, isopropyl alcohol - 146,25 g/l. 


\section{Experiments}

Before disinfection muck, fodder residues, litters were removed from animal breeding premises, disinfection objects were mechanically cleaned. Unessentially thumbed surfaces and electric equipment were subjected to the dry cleaning. The cleaning with prewatering was conducted at preparing to disinfection of the floor, slot grates, troughs, lower part of the walls, fencing constructions. Before that they were watered by 2,0 \% hot solution of caustic soda. After that in 30 minutes the premises were washed by the water filament under pressure. The cleaning of the premise was finished by eliminating water from troughs and drinking bowls, the premise was dried.

After that the moist disinfection was conducted. For this aim in the first case the preparation "Hermicidan FF plus" was used in concentration $0,1 \%, 0,25 \%, 0,5 \%, 1,0 \%$ at exposition $30 \mathrm{~min}$ and 1 hour, in the first one - disinfectant "Peroxan Forte" in concentration $0,1 \%, 0,2 \%, 0,5 \%$, $1,0 \%$ at exposition $30 \mathrm{~min}-1$ hour, and in the third one - disinfecting means "Viro xal" in concentration $0,1 \%, 0,2 \%, 0,5 \%, 1,0 \%$ at exposition $1-3$ hours at application rate of water solutions of disinfectants $0,51 / \mathrm{m}^{2}$.

An exposition, at which the studies of the preparations were conducted, was chosen under guidance of laboratory studies, at which these preparations manifested bactericidal properties. Thus, the disinfecting means "Viro xal" during $30 \mathrm{~min}$ had not manifested bactericidal properties, and the exposition time was increased.

The quality of the conducted disinfection was controlled by separation of sanitary-representative microorganisms - bacteria of the colon bacillus group [9].

\section{Results}

After conducting the mechanical cleaning and estimating its quality, the disinfection by the preparations "Hermicidan FF plus", "Peroxan Forte" and "Viro xal" was realized using pneumatic sprayers.

As a result of the conducted cultural studied of washouts, taken before the disinfection, microorganisms of Enterobacteriaceae spp. and Staphylococcus spp. genera, yeast fungi were separated.

The results of using the disinfecting preparation "Hermicidan FF plus" are presented in Table 1.

Table 1

Results of using the disinfecting preparation "Hermicidan FF plus"

\begin{tabular}{|c|c|c|c|}
\hline \multirow{2}{*}{ Concentration } & \multirow{2}{*}{ Exposition } & \multicolumn{2}{|c|}{ Microflora growth } \\
\hline & & Before disinfection & After disinfection \\
\hline \multirow{2}{*}{$0,1 \%$} & $30 \mathrm{~min}$ & + & + \\
\hline & 1 hour & + & + \\
\hline \multirow{2}{*}{$0,25 \%$} & $30 \mathrm{~min}$ & + & + \\
\hline & 1 hour & + & + \\
\hline \multirow{2}{*}{$0,5 \%$} & $30 \mathrm{~min}$ & + & + \\
\hline & 1 hour & + & - \\
\hline \multirow{2}{*}{$1,0 \%$} & $30 \mathrm{~min}$ & + & + \\
\hline & 1 hour & + & - \\
\hline
\end{tabular}

At analyzing the research results, presented in Table 1, we can see that the disinfecting preparation "Hermicidan FF plus" in concentration 0,1-0,25\% at exposition $30 \mathrm{~min}-1$ hour and also in concentration $0,5-1,0 \%$ at exposition $30 \mathrm{~min}$ doesn't eliminate microorganisms on objects of the animal breeding premises completely, and at the same time the growth of staphylococcus and colon bacillus on the nutritive medium surface was observed. At the same time it was established, that at sanitation by the preparation in concentration $0,5-1,0 \%$ at exposition 1 hour and application norm $0,51 / \mathrm{m}^{2}$ sanitary-representative microorganisms were not eliminated from washouts, 
collected after disinfecting, that testifies to the presence of bactericidal properties of the applied disinfectant.

The results of using the disinfecting preparation "Peroxan Forte" are presented in Table 2.

Table 2

Results of using the disinfecting preparation "Peroxan Forte"

\begin{tabular}{|c|c|c|c|}
\hline \multirow{2}{*}{ Concentration } & \multirow{2}{*}{ Exposition } & \multicolumn{2}{|c|}{ Microflora growth } \\
\hline & & Before disinfection & After disinfection \\
\hline \multirow{2}{*}{$0,1 \%$} & $30 \mathrm{~min}$ & + & + \\
\hline & 1 hour & + & + \\
\hline \multirow{2}{*}{$0,2 \%$} & $30 \mathrm{~min}$ & + & + \\
\hline & 1 hour & + & + \\
\hline \multirow{2}{*}{$0,5 \%$} & $30 \mathrm{~min}$ & + & + \\
\hline & 1 hour & + & + \\
\hline \multirow{2}{*}{$1,0 \%$} & $30 \mathrm{~min}$ & + & + \\
\hline & 1 hour & + & - \\
\hline
\end{tabular}

At analyzing the research results, presented in Table 2, we can see that the disinfecting preparation "Peroxan Forte" can be applied for disinfecting animal breeding premises in concentration $1,0 \%$ at exposition 1 hour and application rate $0,51 / \mathrm{m}^{2}$ of a summary area of processed surfaces. At the same time the growth of sanitary-representative microorganisms on nutritive mediums was observed in inoculations from washouts, taken after using the preparation in concentration $0,1-0,5 \%$, and also $1,0 \%$ at exposition $30 \mathrm{~min}$.

The results of using the disinfecting preparation "Viro xal" are presented in Table 3.

Table 3

Results of using the disinfecting preparation "Viro xal"

\begin{tabular}{|c|c|c|c|}
\hline \multirow{2}{*}{ Concentration } & \multirow{2}{*}{ Exposition } & \multicolumn{2}{|c|}{ Microflora growth } \\
\hline & & Before disinfection & After disinfection \\
\hline \multirow{2}{*}{$0,1 \%$} & 1 hour & + & + \\
\hline & 3 hours & + & + \\
\hline \multirow{2}{*}{$0,2 \%$} & 1 hour & + & + \\
\hline & 3 hours & + & + \\
\hline \multirow{2}{*}{$0,5 \%$} & 1 hour & + & + \\
\hline & 3 hours & + & + \\
\hline \multirow{2}{*}{$1,0 \%$} & 1 hour & + & + \\
\hline & 3 hours & + & - \\
\hline
\end{tabular}

Note: «+»-growth; «-»-no growth

The research results, presented in Table 3, demonstrate that the preparation "Viro xal" manifests disinfecting properties directly under production conditions at using in concentration $1,0 \%$ at exposition 3 hours and application norm $0,51 / \mathrm{m}^{2}$. At the same time there was established its low effectiveness in concentration $0,1-0,5 \%$, and also in concentration $1,0 \%$ at exposition 1 hour.

The results, obtained at the conducted experiments, gives a possibility to widen the assortment of disinfecting preparations that may be used in animal breeding for providing animals' welfare with getting products of the correspondent quality. 
Keeping of production premises in the conditions, correspondent to zoo-hygienic requirements is at the same time prophylaxis of appearing and spreading infectious diseases of agricultural animals.

The important factor of animal production technologies is a unity of hygiene and prophylaxis, creation of the anti-microbial regime in production premises for animals, without which a specific immune prophylaxis is low-effective. Thus, keeping of the high sanitary culture of production premises, hygiene of animals themselves, fodders, water and technical means is included in the general production process.

The high concentration of agricultural animals at limited territories can cause appearance and spread of infectious diseases. Disinfection is an unalienable and at the same time one of important parts of the general program of prophylaxis and fight against infectious pathologies at animal breeding enterprises. At planning veterinary-sanitary arrangements, a series of factors that influence their final efficiency must be taken into account: high air contamination of production premises, fodders by conventionally-pathogenic and pathogenic microorganisms and presence of strains, resistant to most used anti-microbial preparations and disinfectants in biocenosis.

At preventing appearance, spread and at liquidating infectious diseases of agricultural animals, the important role belongs to disinfecting arrangements that provide a break of the epizootic chain by eliminating pathogenic microorganisms from environment objects [10]. The diversity of sources, ways and factors of transmitting causative agents of infectious diseases conditions the necessity of developing and introducing in practice scientifically grounded modern disinfecting technologies [11]. Thus, in the last decade there was developed and regulated the production of new chemical, physical and biological disinfecting means, correspondent conditions and methods of disinfection of different surfaces on food industrial, transport, animal husbandry objects. Introduction of many preparations, different by their properties, in practical disinfectology made the problem of their optimal choice for solving a concrete task urgent [12, 13]. At first there are determined the main factors (microorganisms that must be eliminated, types of disinfected objects, processing regimes, consumption properties of disinfecting means, their cost) that must be taken into account for making decisions, then there are determined the importance and level of each of them and the generalizing criterion that gives a possibility to make an unambiguous decision is formed.

\section{Conclusions}

It has been established, that the disinfecting preparations "Hermicidan FF plus", "Peroxan forte", "Viro-xal" have bactericidal properties relative to the sanitary-representative microorganisms and can be used in the general complex of sanitary-hygienic arrangements.

The disinfectant "Hermicidan FF plus" has bactericidal properties in concentration 0,5\% at exposition 1 hour, preparation "Peroxan Forte" is effective at using in concentration 1,0\% at exposition 1 hour, and the disinfecting means "Viro xal" acts bactericidially in concentration $1,0 \%$ at exposition 3 hours.

For today the question of search for new technological, high-effective disinfecting preparations that correspond to existent requirements of biological safety and protection in the general structure of animal husbandry products making remains urgent.

\section{References}

[1] Ley, B., Silverman, E., Peery, K., Dominguez, D. (2016). Evaluation of Commonly Used Products for Disinfecting Clipper Blades in Veterinary Practices: A Pilot Study. Journal of the American Animal Hospital Association, 52 (5), $277-280$. doi: http://doi.org/10.5326/jaaha-ms-6427

[2] Palii, A. P. (2016). Innovatsiini osnovy oderzhannia vysokoiakisnoho moloka. Kharkiv: Miskdruk, 270.

[3] Powell, L. F., Cheney, T. E. A., Williamson, S., Guy, E., Smith, R. P., Davies, R. H. (2015). A prevalence study of Salmonella spp., Yersinia spp., Toxoplasma gondii and porcine reproductive and respiratory syndrome virus in UK pigs at slaughter. Epidemiology and Infection, 144 (7), 1538-1549. doi: http://doi.org/10.1017/s0950268815002794

[4] Gygli, S. M., Borrell, S., Trauner, A., Gagneux, S. (2017). Antimicrobial resistance in Mycobacterium tuberculosis: mechanistic and evolutionary perspectives. FEMS Microbiology Reviews, 41 (3), 354-373. doi: http://doi.org/10.1093/femsre/fux011 
[5] Rutala, W. A., Weber, D. J. (2013). Disinfectants used for environmental disinfection and new room decontamination technology. American Journal of Infection Control, 41 (5), 36-41. doi: http://doi.org/10.1016/j.ajic.2012.11.006

[6] Kochish, I. I., Kolomiets, S. N., Smirnov, S. L., Kochish, O. I. (2014). Izuchenie bakteritsidnogo deistviia preparata Anolit ANK. Vetkorm, 2, 30-31.

[7] Paliy, A. P., Ishchenko, K. V., Marchenko, M. V., Paliy, A. P., Dubin, R. A. (2018). Effectiveness of aldehyde disinfectant against the causative agents of tuberculosis in domestic animals and birds. Ukrainian Journal of Ecology, 8 (1), $845-850$. doi: http://doi.org/10.15421/2018_283

[8] Hualpa, D., Ludena, F. (2015). Evaluation Germicidal of Disinfectants on Staphylococcus aureus and Escherichia coli. Journal of Bacteriology \& Parasitology, s2. doi: http://doi.org/10.4172/2155-9597.1000232

[9] Instruktsiia z provedennia sanitarnoi obrobky - dezinfektsii, dezinsektsii ta deratyzatsii obiektiv ptakhivnytstva (2007). Zatverdzhena nakazom Derzhavnoho departamentu veterynarnoi medytsyny Ministerstva ahrarnoi polityky Ukrainy 69. 20.06.2007.

[10] Haute, S. van, Sampers, I., Jacxsens, L., Uyttendaele, M. (2013). Selection Criteria for Water Disinfection Techniques in Agricultural Practices. Critical Reviews in Food Science and Nutrition, 55 (11), 1529-1551. doi: http://doi.org/10.1080/10408398. 2012.705360

[11] McLaren, I., Wales, A., Breslin, M., Davies, R. (2011). Evaluation of commonly-used farm disinfectants in wet and dry models ofSalmonellafarm contamination. Avian Pathology, 40 (1), 33-42. doi: http://doi.org/10.1080/03079457.2010.537303

[12] Palii, A. P., Palii, A. P. (2019). Tekhniko-tekhnolohichni innovatsii u molochnomu skotarstvi. Kharkiv: Miskdruk, 324.

[13] Boyce, J. M., Sullivan, L., Booker, A., Baker, J. (2015). Quaternary Ammonium Disinfectant Issues Encountered in an Environmental Services Department. Infection Control \& Hospital Epidemiology, 37 (3), 340-342. doi: http://doi.org/10.1017/ ice.2015.299

Received date 22.05.2019

Accepted date 25.06.2019

Published date 31.07.2019
(C) The Author(s) 2019

This is an open access article under the CC BY license (http://creativecommons.org/licenses/by/4.0). 